\title{
Insulin Resistance in HIV-Patients: Causes and Consequences
}

\author{
Marcelo N. Pedro ${ }^{1 \dagger}$, Guilherme Z. Rocha ${ }^{1 \dagger}$, Dioze Guadagnini ${ }^{1}$, Andrey Santos ${ }^{1}$, \\ Daniela O. Magro ${ }^{2}$, Heloisa B. Assalin ${ }^{1}$, Alexandre G. Oliveira ${ }^{1,3}$, Rogerio de Jesus Pedro ${ }^{1}$ \\ and Mario J. A. Saad ${ }^{\text {* }}$ \\ ${ }^{1}$ Department of Internal Medicine, Faculty of Medical Sciences, State University of Campinas-UNICAMP, Campinas, Brazil, \\ ${ }^{2}$ Department of Surgery, Faculty of Medical Sciences, State University of Campinas-UNICAMP, Campinas, Brazil, \\ ${ }^{3}$ Biosciences Institute, São Paulo State University (UNESP), Rio Claro, Brazil
}

\section{OPEN ACCESS}

Edited by:

Andrew J. McAinch Victoria University, Australia

Reviewed by:

Caterina Conte, Università Vita-Salute San Raffaele,

Italy

Kathleen Grace Mountjoy, University of Auckland, New Zealand

*Correspondence:

Mario J. A. Saad msaad@fcm.unicamp.br

†These authors have contributed equally to this work

Specialty section: This article was submitted to

Obesity,

a section of the journal

Frontiers in Endocrinology

Received: 28 May 2018 Accepted: 16 August 2018 Published: 05 September 2018

Citation

Pedro MN, Rocha GZ, Guadagnini D, Santos A, Magro DO, Assalin HB,

Oliveira AG, Pedro RdJ and Saad MJA (2018) Insulin Resistance in

HIV-Patients: Causes and Consequences.

Front. Endocrinol. 9:514. doi: 10.3389/fendo.2018.00514
Here we review how immune activation and insulin resistance contribute to the metabolic alterations observed in HIV-infected patients, and how these alterations increase the risk of developing CVD. The introduction and evolution of antiretroviral drugs over the past 25 years has completely changed the clinical prognosis of HIV-infected patients. The deaths of these individuals are now related to atherosclerotic CVDs, rather than from the viral infection itself. However, HIV infection, cART, and intestinal microbiota are associated with immune activation and insulin resistance, which can lead to the development of a variety of diseases and disorders, especially with regards to CVDs. The increase in LPS and proinflammatory cytokines circulating levels and intracellular mechanisms activate serine kinases, resulting in insulin receptor substrate-1 (IRS-1) serine phosphorylation and consequently a down regulation in insulin signaling. While lifestyle modifications and pharmaceutical interventions can be employed to treat these altered metabolic functions, the mechanisms involved in the development of these chronic complications remain largely unresolved. The elucidation and understanding of these mechanisms will give rise to new classes of drugs that will further improve the quality of life of HIV-infected patients, over the age of 50 .

Keywords: insulin resistance, diabetes, HIV, CVD, CART, LPS

\section{INTRODUCTION}

The introduction and evolution of antiretroviral drugs over the past 25 years has completely changed the clinical prognosis of HIV-infected patients (1). These drugs have transformed the disease into a chronic condition, and increased life expectancy, which is similar to the general uninfected population (2). Nowadays, the deaths of HIV-infected individuals, who appropriately follow their therapy regimen, are related to non-communicable and HIV-related chronic diseases, mainly atherosclerotic cardiovascular disease (CVD) (3-6). Some of the mechanisms responsible for this increased cardiovascular risk, in HIV-infected patients, involve HIV infection and inflammation, dyslipidemia, insulin resistance, as well as metabolic, and body composition changes induced by antiretroviral therapy (7-11). Moreover, non-HIV related risk factors, such as aging, can also contribute to the development of these metabolic alterations and risk factors (12-15).

Here we review how immune activation and insulin resistance contribute to the metabolic alterations observed in HIV-infected patients, and how these alterations increase the risk of developing CVD. In section Sources of Immune Activation and Insulin Resistance in HIV Patients, we discuss how HIV infection and inflammation, combination antiretroviral therapy (cART), and 
gut microbiota contribute to immune activation and insulin resistance. In section Consequences of Immune Activation and Insulin Resistance in HIV-Infected Patients, we review the clinical consequences of immune activation and insulin resistance, as well as how these processes are involved in the development of age-related metabolic diseases in HIV patients.

\section{SOURCES OF IMMUNE ACTIVATION AND INSULIN RESISTANCE IN HIV PATIENTS}

The immune activation of HIV-infected patients, whether on cART or not, is usually accompanied by insulin resistance (16). In this section, the role of HIV infection and inflammation, cART, and gut microbiota in immune activation and molecular mechanism of insulin resistance are discussed.

\section{Effect of HIV Infection and Inflammation on Insulin Resistance}

It is generally accepted that there is a correlation between innate immune system activation and insulin resistance, which contributes to glucose metabolism dysregulation and dyslipidemia (8). Immune activation results in chronic inflammation, that varies in severity, and has been observed in untreated HIV patients and patients undergoing cART (17). However, untreated HIV-patients display an enhanced inflammatory state, which is characterized by high levels of proinflammatory cytokines, like tumor necrosis factor alpha (TNF- $\alpha$ ), and interleukins (IL-6 and IL-1 $\beta$ ), and is associated with a procoagulant state (12). Under these conditions, the insulin resistance is probably severe and could occur in the liver, muscle, and adipose tissue. In fact, severe insulin resistance in the adipose tissue (as observed in HIV untreated patients), may prevents adipose mass gain as described in mice (18-20) (Figure 1A).

In patients undergoing antiretroviral drug therapy, there is a decrease in proinflammatory cytokines, which do not completely return to normal, thus indicating that some level of inflammation persists (21). A variety of factors, such as: virus production, cytomegalovirus infection, regulatory $\mathrm{T}$-cell loss, and/or lymphoid structure damage could contribute to this persistent inflammation $(22,23)$. There is still insulin resistance, but it is mild or moderate. As previously demonstrated in animal models of obesity $(24,25)$, less severe insulin resistance in adipose tissue allows normal or increased glucose uptake and lipid conversion in this tissue, favoring weight gain and contributing to explain the increase in visceral adipose tissue (VAT) in these patients $(26,27)$ (Figure 1A).

In HIV-treated patients, the activation of the innate immune system and insulin resistance is similar to what has been described in obesity and type 2 diabetes mellitus (DM2) $(28,29)$. The innate immune system and insulin signaling are integrated and toll-like receptors (TLRs), inducible nitric oxide synthase (iNOS), protein kinase $\mathrm{R}$ (PKR), c-Jun $\mathrm{N}$-terminal kinases (JNK), and NF- $\kappa \mathrm{B}$ are connected to the insulin receptor (IR) and its downstream signaling pathway IRS/PI3K/Akt. Upon activation of the innate immune system, proteins involved

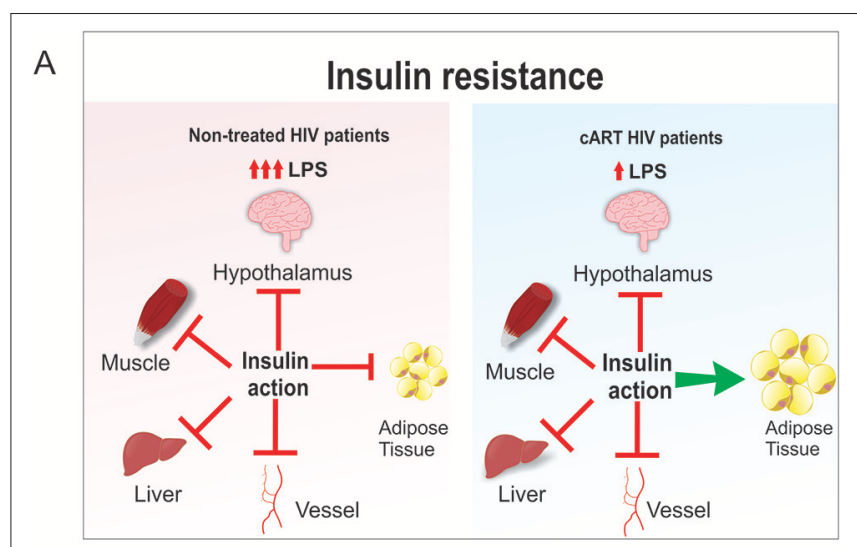

B

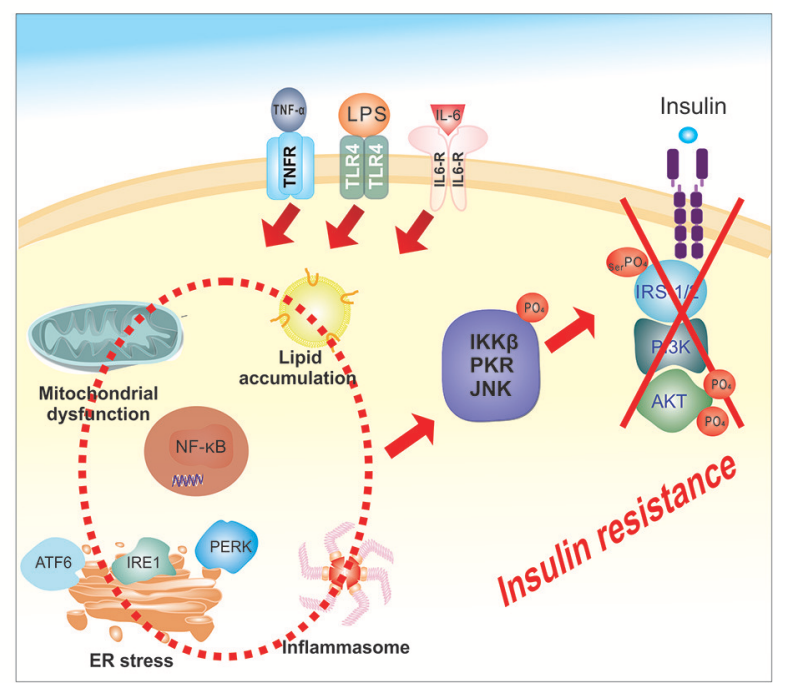

FIGURE 1 | (A) Tissue specific insulin resistance. In HIV untreated patients there is severe insulin resistance with increased LPS and cytokines that involves liver, hypothalamus, muscle, vessels and adipose tissue. After cART treatment the insulin resistance is mild/moderate, with reduced LPS and cytokines that probably spares adipose tissue. (B) Molecular mechanism of LPS-induced insulin resistance. The increase in LPS circulating levels in HIV patients will induce an increase in circulating inflammatory cytokines, and these increases will activate TLR4, IL-6, and TNFalpha receptors, which will induce ER stress, mitochondrial dysfunction, activation of inflammasome and an increase in intracellular lipid accumulation. Then, there will be activation of $\mathrm{PKR}$, JNK, and IKK $\beta / N F-\kappa B$ pathways in liver, muscle, adipose tissue, macrophages and also in other tissues. The activation of these serine kinases (PKR, JNK, and IKK $\beta$ ) will induce serine phosphorylation of the IRS $1 / 2$ and consequently a down regulation in insulin signaling.

in insulin signaling pathways become posttranscriptionally modified, resulting in reduced insulin action (Figure 1B) $(30,31)$.

It is important to mention that bacterial lipopolysaccharide (LPS) from the Gram negative intestinal bacteria is continuously produced in the gut (secondary to death of Gram negative bacteria) and translocated to the circulation (32). This translocation depends on many factors including immune system, integrity of epithelia barrier, diet, and many other environmental factors. The increase in circulating LPS, through its own receptor -TLR4- induce the release of inflammatory cytokines that can contribute to insulin resistance $(33,34)$. 
Previous data showed that there is an increase in LPS circulating levels in HIV patients, whether on treatment or not (35), which can induce at the same time TLR4 activation and endoplasmic reticulum (ER) stress $(19,36,37)$. Then, there will be activation of PKR, JNK, and IKK $\beta / N F-\kappa B$ pathways in liver, muscle, adipose tissue, macrophages, and also in other tissues. The activation of these serine kinases (PKR, JNK, and IKK $\beta$ ) will induce serine phosphorylation of the insulin receptor substrate 1 and 2, and consequently a down regulation in insulin signaling $(38,39)$. The activation of NF- $\kappa$ B pathways in liver, adipose tissue, and macrophages will induce the production of proinflammatory cytokines (i.e., TNF- $\alpha$, IL-1 $\beta$, and IL-6), creating an inflammatory vicious cycle, which is even worst with the increased adiposity (40-43). Certainly, this aggravates inflammation and insulin resistance.

In addition to increase in circulating LPS and in proinflammatory cytokine TNF- $\alpha$, IL- $1 \beta$, and IL- 6 , the JNK and NF- $\kappa$ B pathways can also be activated by intracellular mechanisms that involve oxidative and endoplasmic reticulum (ER) stresses, activation of inflammasome and an increase in intracellular lipid accumulation (39, 44, 45) (Figure 1B). Additionally, augmented iNOS activity and the nitrosylation of insulin pathway proteins have been shown to promote insulin resistance $(46,47)$. In summary, an increase in LPS and proinflammatory cytokines and in intracellular mechanisms will activate serine kinases, resulting in insulin receptor substrate-1 (IRS-1) serine phosphorylation and insulin signal transduction inhibition $(30,31,48)$.

\section{Effect of Viral Suppression on Insulin Resistance}

Protease inhibitors (PI) or nucleoside analog reverse transcriptase inhibitors (NRTI) have been shown to induce insulin resistance, dyslipidemia, and lipodystrophy, and consequently increase cardiovascular risk (17, 49-51). These drugs increase the nuclear localization of SREBP-1 (sterol regulatory element-binding protein 1 ), which is a transcription factor that regulates the expression of genes associated with lipid synthesis (52). In the liver, these antiviral drugs can increase the levels of free intracellular cholesterol and lipids (53), which can affect aging and the immune system response. In the muscle and adipose tissue, these drugs can induce ER stress and reduce glucose transporter 4 (GLUT4) translocation to the plasma membrane $(54,55)$. The NRTIs also inhibit mitochondrial DNApolymerase, respiratory chain function, and ATP production, ultimately leading to adipocyte death (56-60).

HIV patients undergoing cART exhibit a partial reversal of immune activation and inflammation. Additionally, cART reduces opportunistic infections and cardiovascular risk factors, which is likely a result of some reduction in inflammation (61), although residual markers of inflammation and coagulation remains elevated in ART-treated HIV-infected patients (62). In treated patients the dyslipidemia correlates better with $\mathrm{C}$ reactive protein and IL-6 levels, rather than with CD4 count or HIV viral load, suggesting that immune activation has a central role in the development of dyslipidemia (63). While cART improves some of the observed alterations, it does not reverse the immune activation or chronic inflammation completely. In fact, patients undergoing cART still present a proinflammatory and prothrombotic state, accompanied by changes in the number and size of low-density lipoprotein (LDL) and high-density lipoprotein (HDL) particles, which increases the risk of these patients developing cardiovascular complications (62, 64-67).

\section{Effect of Microbiota Modulation on Insulin Resistance}

While the progression from HIV infection to AIDS is primarily modulated by $\mathrm{T}$ cell activation and systemic inflammation, there is evidence that the gastrointestinal mucosa immune system also participates in this process (68). The human gut microbiota is mainly composed of four phyla: Firmicutes, Bacteroidetes, Actinobacteria, and Proteobacteria. The general population predominantly harbors Bacteroidetes, followed by Firmicutes; however, the composition of the gut microbiota is influenced by diet, age, geography, drugs, and cultural behaviors (69-72). Over the past 10 years, it is becoming clear that microbiota populations are modulated and may have a causal effect in more prevalent chronic conditions such as: obesity, diabetes, hypertension, and CVD (73).

Interestingly, HIV infection can also modulate the levels of bacteria of the gut microbiota. In fact, there is a decrease in the levels of the phylum Bacteroidetes, but some genders of this phylum, as Prevotella, increases when analyzed in treated and untreated patients (74-76). Such a change in the gut microbiota could result in increased tryptophan catabolism, chronic inflammation, and increased cardiovascular risk (77, 78). Additionally, an increase in Prevotella could augment circulating trimethylamine (TMA) levels, which is transformed into trimethylamine oxide (TMAO), and can have a role in the development of atherosclerosis (79).

Previous data showed that increased levels of choline and TMAO are associated with cardiovascular diseases (80). It is well known that ingested choline is transformed by gut microbiota in TMA, which enters portal circulation and in liver is converted in TMAO (80). It is interesting that fasting TMAO levels are independent predictor of atherosclerotic disease and high-risk mortality in coronary artery disease patients (81, 82). The mechanisms by which TMAO induces or accelerates atherosclerosis is not completely understood, it may involve macrophage activation and increase in foam cells and also modulation of platelet aggregation and adhesion (83). Moreover, besides promoting atherosclerosis lesion development, TMAO also aggravate pressure-overload heart failure in mice (84).

Recently, our group demonstrated that, in HIV patients, a close correlation exists between increased circulating LPS levels, a marker for intestinal permeability, and insulin resistance (35). The increased translocation of LPS and elevated serum levels induce the activation of the innate and adaptive immune systems $(35,85,86)$. As discussed previously, in macrophages and most tissues, LPS binds to and activates TLR4, which initiates a complex cascade of signaling events, resulting in the downstream activation of the JNK and NF-kB pathways, and consequently 
insulin resistance and systemic inflammation. Additionally, LPS has also been shown to increase adipose tissue, which augments body weight gain $(35,87,88)$. Moreover, in HIV-infected patients, elevated levels of LPS have been linked to endothelial dysfunction and adverse metabolic outcomes (35, 88-91).

It is important to mention that the effect of cART introduction in the modulation of gut microbiota is not completely understood. However, very recently Ji et al. showed that this modulation after cART was differentially correlated with the immune status, especially in patients with CD4 $+\mathrm{T}$ cell counts $>300 / \mathrm{mm}^{3}$ (92). In these patients it was shown that the alpha diversity was correlated with CD $4+\mathrm{T}$ cell counts, but the specific role of cART in increasing microbial diversity is still controversial $(78,92,93)$. This correlation may explain the conflicting results in previous studies investigating alpha diversity in intestinal microbiota in HIV patients (93-96), indicating that this diversity is consequence of the immune status of the subjects. The immunological profile and cART seem to contribute together to alter the gut microbiota.

\section{CONSEQUENCES OF IMMUNE ACTIVATION AND INSULIN RESISTANCE IN HIV-INFECTED PATIENTS}

Chronic immune activation and insulin resistance can contribute to obesity, dyslipidemia, CVDs, and non-alcoholic fat liver disease (NAFLD) as well as neurocognitive disorders, metabolic disorders, bone abnormalities, and non-HIV associated cancers $(12,97-99)$. While the evolution of these complications depends on genetic and environmental factors, each condition has the potential of aggravating another (Figure 2).

\section{Obesity and Lipodystrophy}

Before the new generation of antiretroviral therapies, HIV was often associated with lipodystrophy, which is a marker for metabolic alterations and includes a broad spectrum of clinical alterations $(100,101)$. Previous studies showed that HIV infection severity was associated with an increased prevalence of lipodystrophy, which is secondary to HIV-infected macrophages infiltration and enhanced local inflammation in the adipose tissue $(102,103)$. In the past, the development of lipodystrophy was partially related to drugs (i.e., stavudine and zidovudine) included in the treatment regimen, but it is also influenced by age, CD4 levels, viral load, therapy duration, and race (especially caucasians). Remarkably, the new classes of cART and inhibitors (fusion, integrase, and entry) do not alter the metabolic parameters of fat distribution (1, 50).

Obesity and visceral adiposity are commonly observed in HIV-treated patients and are the result of factors associated with both traditional treatments and cART. As with most obese people, the increase in adipose tissue is associated with inflammatory and metabolic responses. Since many HIV patients have low muscle mass, excess adipose tissue may be present, even when the BMI is within the normal range. In fact, a recent study showed that when considering BMI, $60-70 \%$ of HIV-infected

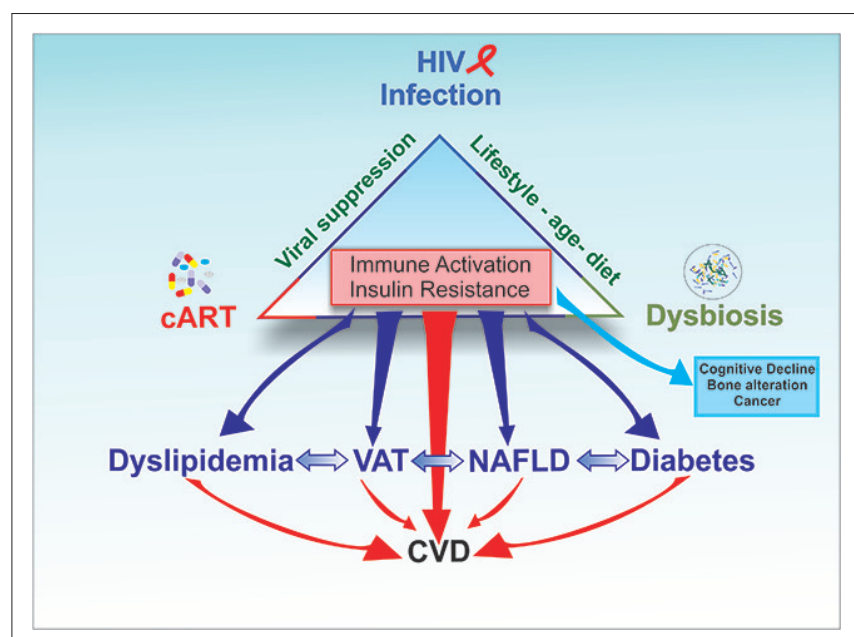

FIGURE 2 | The triad HIV infection/inflammation, antiretroviral therapy (cART), and gut microbiota contribute to induce immune activation and insulin resistance. The clinical consequences of chronic immune activation and insulin resistance can contribute to increase Visceral Adipose Tissue (VAT), dyslipidemia, CVDs and non-alcoholic fat liver disease (NAFLD) as well as neurocognitive disorders, metabolic disorders, bone abnormalities and non-HIV associated cancers While the evolution of these complications depends on genetic and environmental factors, each condition has the potential of aggravating another, increasing the risk of CVD in HIV patients.

patients are considered overweight or obese (104-108). In most patients, there is an increase in visceral adipose tissue (VAT), which is usually indicative of a more deleterious metabolic profile (109-111).

In obese populations, metabolically healthy obesity is characterized by less VAT and reduced inflammation (112115). These same more benign metabolic conditions have also been documented in some HIV infected patients considered overweight or obese. The reasons why some obese individuals, with or without HIV, have a more aggressive metabolic profile and associated risk factors are not completely understood, but it might involve adipocyte size and/or number, recruited inflammatory cells, hypoxia, and/or adiponectin levels (116118).

The extrapolation of data from the obese population without HIV to those with HIV must be interpreted with care, since a large portion of the data related to adipose tissue dysfunction includes HIV patients with lipodystrophy. Although this alteration in fat distribution still occurs in treated HIVinfected patients, the prevalence of obesity is increasing, and in some patients, an association between obesity and lipodystrophy has been observed (119).

\section{Dyslipidemia}

During the 80's and early 90's, before the introduction of antiretroviral therapy, dyslipidemia was evident in more severe HIV cases, and was characterized by high triglyceride (TG) levels and low levels of HDL-cholesterol (HDL-C) and LDLcholesterol (LDL-C). Although the exact mechanisms that account for the development of this kind of dyslipidemia are not fully understood, there is data suggesting that it may be 
induced by insulin resistance resulting from HIV infection and inflammation (120-122). This observed pattern of dyslipidemia is not only observed in HIV patients, but is also detected in other infections and inflammations, and can become atherogenic if it persists $(123,124)$. In this regard, an increase in TNF- $\alpha$ level can impair the clearance of TGs and reduce the antilipolytic effect of insulin, thus stimulating lipolysis in HIV-patients with lipodystrophy.

Besides activation of the innate immune system and insulin resistance, which contributes to glucose metabolism dysregulation and dyslipidemia, other mechanisms may also contribute to explain this pattern of dyslipidemia. One such mechanism involves the adenosine-triphosphate binding cassette transporter A1 (ABCA1), a transmembrane transporter present in macrophages, which interacts with the HIVproduced accessory protein Nef. Under physiological conditions, ABCA1 shuttles cholesterol from macrophages (in peripheral tissues) to HDL, which was previously shown to be to reduce cardiovascular risk $(87,125)$. However, in HIVinfected patients, Nef downregulates ABCA1 expression and reduces the efflux of cholesterol to HDL. As a result, lipid accumulates inside the macrophage, and is transformed into foam cells, which is associated with atherosclerosis (125).

Another mechanism, that can contribute to the understanding of why this pattern of dyslipidemia is commonly observed in HIV-patients, is through the inhibition of an intracellular peroxisome protein, proliferatoractivated receptor gamma (PPAR- $\gamma$ ) (126). This protein is critical for adipocyte differentiation, and is inhibited by the HIV viral protein, vpr. The inhibition of PPAR$\gamma$ blocks adipocyte differentiation, and leads to fatty acid accumulation and lipotoxicity. Moreover, HIV replication is also associated with an increase in fatty acid synthase (FAS) activity, which impacts fatty acid synthesis (127). These data suggest that in $\mathrm{HIV}$-infected patients, not undergoing cART, there is an increase in fatty acid production that can contribute to the appearance of dyslipidemia and insulin resistance.

On the other side, it has been shown that cART not only suppresses HIV infection and reduces inflammation, but it also changes the dyslipidemia pattern, which is characterized by an increase in TGs and LDL-C, a reduction in HDL-C and maintenance of insulin resistance $(128,129)$. In fact, a recent meta-analysis study showed that cART patients have a higher risk of developing hypercholesterolemia and display higher TG levels than non-treated HIV patients (27). The previously described modulation of ABCA1 by Nef, which reduces the efflux of HDL, is also reversed by cART (130-132).

\section{Cardiovascular Diseases and NAFLD}

As previously mentioned, there is still an increased risk of CVD in the HIV-infected population, despite cART and the control of risk factors $(1,51)$. Even with the development of new antiretroviral drugs, the chronic immune activation and insulin resistance remain and contribute to this greater risk $(12,51)$. Also, recent data has shown that HIV-infected patients can present left ventricular systolic and diastolic dysfunction and myocardial fibrosis $(133,134)$.

Abnormal liver enzymes are also common in HIV-infected patients, despite the absence of alcohol consumption or viral hepatitis. These abnormalities have been associated with an increased prevalence of NAFLD and non-alcoholic steatohepatitis (NASH) (135). The actual prevalence of NAFLD and NASH in HIV-infected patients is not known because the methods used to define these alterations vary among studies (136). Recent data has shown that in HIV-infected patients, treated with cART, the prevalence of NAFLD is around $40 \%$, and that these patients have a higher risk of developing NASH or cirrhosis than obese patients without HIV (137141). These hepatic alterations are secondary to multiple factors, and immune activation, insulin resistance, cART, and aging are certainly involved in the process. It is also important to mention that NAFLD is a risk factor for diabetes and CVDs (142).

\section{Neurocognitive Disorders, Metabolic Disorders, Bone Abnormalities, and Non-HIV Associated Cancers}

The HIV-infected population can develop behavioral abnormalities, motor dysfunction, and dementia (12). The clinical presentation can vary from mild neurocognitive disorders to severe HIV-associated dementia $(143,144)$. The prevalence of these abnormalities is $~ 50 \%$ (145), however, since the introduction of modern cART, the prevalence of severe forms of neurocognitive disorders has been dramatically reduced (146).

With regards to glucose metabolism, it is clear that current cART is much less metabolically toxic than previous therapies. However, HIV and cART are independently associated with glucose intolerance and diabetes (49). Again, while these abnormalities are secondary to multiple factors, glucose intolerance and diabetes are known to exacerbate the risk of these patients developing CVD.

Recent data has shown that HIV-infected patients have fracture rates three times higher than the control population $(147,148)$. In fact, decreased bone mineral density, osteopenia, and osteoporosis have been observed in these patients, and are probably related to immune activation and systemic inflammation, cART, low vitamin $\mathrm{D}$, and/or aging.

The risk of some non HIV-associated cancers is 50\% higher in HIV-infected patients than in non-infected patients $(149,150)$. For example, HIV infection is associated with a higher incidence of virus-related cancers such as: Kaposi sarcoma, lymphomas, and anal and liver cancer, which is most likely secondary to the poor immunological control of oncogenic viruses (12).

Overall, recent data showed that the mortality of HIV-infected people decreased in those below 65 years old, but increased after this age $(112,115)$, which is likely due to the increased risk of developing CVDs and dying from acute coronary syndrome. Furthermore, there is also an increase in the occurrence of coronary artery disease in young HIV-infected patients, when compared with the uninfected control population $(113,114,151)$. 


\section{CONCLUSION}

The introduction of antiretroviral drugs has changed the clinical prognosis of HIV-infected patients and the deaths of these individuals are now related to atherosclerotic CVDs, rather than from the viral infection itself. However, HIV infection, cART, and intestinal microbiota are associated with immune activation and insulin resistance, which can lead to the development of a variety of diseases and disorders, especially with regards to CVDs. While lifestyle modifications and pharmaceutical interventions can be employed to treat these altered metabolic functions, the mechanisms involved in the development of these chronic complications remain largely unresolved. The elucidation and understanding of these mechanisms will give rise to new classes of drugs that will further improve the quality of life of HIV-infected patients, over the age of 50.

\section{REFERENCES}

1. Ghosn J, Taiwo B, Seedat S, Autran B, Katlama C. HIV. Lancet (2018) 392:685-97. doi: 10.1016/S0140-6736(18)31311-4

2. Walensky RP, Paltiel AD, Losina E, Mercincavage LM, Schackman BR, Sax PE, et al. The survival benefits of AIDS treatment in the United States. J Infect Dis. (2006) 194:11-9. doi: 10.1086/505147

3. Lewden C, Bouteloup V, De Wit S, Sabin C, Mocroft A, Wasmuth JC, et al. All-cause mortality in treated HIV-infected adults with CD $4>/=500 / \mathrm{mm} 3$ compared with the general population: evidence from a large European observational cohort collaboration. Int J Epidemiol. (2012) 41:433-45. doi: 10.1093/ije/dyr164

4. Lohse N, Hansen AB, Pedersen G, Kronborg G, Gerstoft J, Sørensen HT, et al. Survival of persons with and without HIV infection in Denmark, 1995-2005. Ann Intern Med. (2007) 146:87-95. doi: 10.7326/0003-4819-146-2-200701160-00003

5. Sackoff JE, Hanna DB, Pfeiffer MR, Torian LV. Causes of death among persons with AIDS in the era of highly active antiretroviral therapy: New York City. Ann Intern Med. (2006) 145:397-406. doi: 10.7326/0003-4819-145-6-200609190-00003

6. Kim JH, Psevdos G, Gonzalez E, Singh S, Kilayko MC, Sharp V. All-cause mortality in hospitalized HIV-infected patients at an acute tertiary care hospital with a comprehensive outpatient HIV care program in New York City in the era of highly active antiretroviral therapy (HAART). Infection (2013) 41:545-51. doi: 10.1007/s15010-012-0386-7

7. Cerrato E, Calcagno A, D'Ascenzo F, Biondi-Zoccai G, Mancone M, Grosso Marra W, et al. Cardiovascular disease in HIV patients: from bench to bedside and backwards. Open Heart (2015) 2:e000174. doi: 10.1136/openhrt-2014-000174

8. Grunfeld C, Pang M, Doerrler W, Shigenaga JK, Jensen P, Feingold KR. Lipids, lipoproteins, triglyceride clearance, and cytokines in human immunodeficiency virus infection and the acquired immunodeficiency syndrome. J Clin Endocrinol Metab. (1992) 74:1045-52.

9. Anuurad E, Semrad A, Berglund L. Human immunodeficiency virus and highly active antiretroviral therapy-associated metabolic disorders and risk factors for cardiovascular disease. Metab Syndr Relat Disord. (2009) 7:401-10. doi: 10.1089/met.2008.0096

10. Lake JE, Currier JS. Metabolic disease in HIV infection. Lancet Infect Dis. (2013) 13:964-75. doi: 10.1016/S1473-3099(13)70271-8

11. Grunfeld C. Dyslipidemia and its treatment in HIV infection. Top HIV Med. (2010) 18:112-8.

12. Nasi M, De Biasi S, Gibellini L, Bianchini E, Pecorini S, Bacca V, et al. Ageing and inflammation in patients with HIV infection. Clin Exp Immunol. (2017) 187:44-52. doi: 10.1111/cei.12814

13. Justice AC. HIV and aging: time for a new paradigm. Curr HIV/AIDS Rep. (2010) 7:69-76. doi: 10.1007/s11904-010-0041-9

\section{AUTHOR CONTRIBUTIONS}

MP and GR contributed to discussions and wrote, edited, and reviewed the article. DG, DM, HA, AO, and RP edited and reviewed the article. AS prepared to figures of the article, edited, and reviewed the article. MS contributed to discussions and wrote and reviewed the article. All authors approved the final version.

\section{FUNDING}

We also acknowledge the financial support CEPID/Fapesp 201307607-8, OCRC (Obesity and Comorbidities Research Center), INCT (National Institute of Science and Technology for Diabetes and Obesity), 465693/2014-8 and CAPES/CNPq (Conselho Nacional de Desenvolvimento Científico e Tecnológico).

14. Guaraldi G, Prakash M, Moecklinghoff C, Stellbrink HJ. Morbidity in older HIV-infected patients: impact of long-term antiretroviral use. AIDS Rev. (2014) 16:75-89.

15. Collaboration ATC. Life expectancy of individuals on combination antiretroviral therapy in high-income countries: A collaborative analysis of 14 cohort studies. Lancet (2008) 372:293-9. doi: 10.1016/S0140-6736(08)61113-7

16. Kiage JN, Heimburger DC, Nyirenda CK, Wellons MF, Bagchi S, Chi BH, et al. Cardiometabolic risk factors among HIV patients on antiretroviral therapy. Lipids Health Dis. (2013) 12:50. doi: 10.1186/1476-511X-12-50

17. Non LR, Escota GV, Powderly WG. HIV and its relationship to insulin resistance and lipid abnormalities. Transl Res. (2017) 183:41-56. doi: 10.1016/j.trsl.2016.12.007

18. Blüher M, Kahn BB, Kahn CR. Extended longevity in mice lacking the insulin receptor in adipose tissue. Science (2003) 299:572-4. doi: $10.1126 /$ science.1078223

19. Blüher M, Michael MD, Peroni OD, Ueki K, Carter N, Kahn BB, et al. Adipose tissue selective insulin receptor knockout protects against obesity and obesity-related glucose intolerance. Dev Cell (2002) 3:25-38. doi: 10.1016/S1534-5807(02)00199-5

20. Blüher M, Wilson-Fritch L, Leszyk J, Laustsen PG, Corvera S, Kahn CR. Role of insulin action and cell size on protein expression patterns in adipocytes. $J$ Biol Chem. (2004) 279:31902-9. doi: 10.1074/jbc.M404570200

21. Neuhaus J, Jacobs DR, Baker JV, Calmy A, Duprez D, La Rosa A, et al. Markers of inflammation, coagulation, and renal function are elevated in adults with HIV infection. J Infect Dis. (2010) 201:1788-95. doi: $10.1086 / 652749$

22. Naeger DM, Martin JN, Sinclair E, Hunt PW, Bangsberg DR, Hecht F, et al. Cytomegalovirus-specific $\mathrm{T}$ cells persist at very high levels during longterm antiretroviral treatment of HIV disease. PLoS ONE (2010) 5:e8886. doi: 10.1371/journal.pone.0008886

23. Schacker TW, Nguyen PL, Beilman GJ, Wolinsky S, Larson M, Reilly C, et al. Collagen deposition in HIV-1 infected lymphatic tissues and T cell homeostasis. J Clin Invest. (2002) 110:1133-9. doi: 10.1172/JCI02 16413

24. Prada PO, Zecchin HG, Gasparetti AL, Torsoni MA, Ueno M, Hirata $\mathrm{AE}$, et al. Western diet modulates insulin signaling, c-Jun N-terminal kinase activity, and insulin receptor substrate-1ser307 phosphorylation in a tissue-specific fashion. Endocrinology (2005) 146:1576-87. doi: 10.1210/en.2004-0767

25. Thirone AC, Carvalheira JB, Hirata AE, Velloso LA, Saad MJ. Regulation of Cbl-associated protein/Cbl pathway in muscle and adipose tissues of two animal models of insulin resistance. Endocrinology (2004) 145:281-93. doi: 10.1210/en.2003-0575

26. Srinivasa S, Fitch KV, Wong K, Torriani M, Mayhew C, Stanley T, et al. RAAS activation is associated with visceral adiposity and insulin resistance 
among HIV-infected patients. J Clin Endocrinol Metab. (2015) 100:2873-82. doi: 10.1210/jc.2015-1461

27. Calza L, Manfredi R, Chiodo F. Insulin resistance and diabetes mellitus in HIV-infected patients receiving antiretroviral therapy. Metab Syndr Relat Disord. (2004) 2:241-50. doi: 10.1089/met.2004.2.241

28. Duncan AD, Goff LM, Peters BS: Type 2 diabetes prevalence and its risk factors in HIV: A cross-sectional study. PLoS ONE (2018) 13:e0194199. doi: 10.1371/journal.pone.0194199

29. Monroe AK, Glesby MJ, Brown TT. Diagnosing and managing diabetes in HIV-infected patients: current concepts. Clin Infect Dis. (2015) 60:453-62. doi: $10.1093 /$ cid/ciu779

30. Carvalho BM, Oliveira AG, Ueno M, Araújo TG, Guadagnini D, CarvalhoFilho MA, et al. Modulation of double-stranded RNA-activated protein kinase in insulin sensitive tissues of obese humans. Obesity (2013) 21:2452-7. doi: 10.1002/oby.20410

31. Carvalho-Filho MA, Carvalho BM, Oliveira AG, Guadagnini D, Ueno M, Dias MM, et al. Double-stranded RNA-activated protein kinase is a key modulator of insulin sensitivity in physiological conditions and in obesity in mice. Endocrinology (2012) 153:5261-74. doi: 10.1210/en.2012-1400

32. Neal MD, Leaphart C, Levy R, Prince J, Billiar TR, Watkins S, et al. Enterocyte TLR4 mediates phagocytosis and translocation of bacteria across the intestinal barrier. J Immunol. (2006) 176:3070-9. doi: 10.4049/jimmunol.176.5.3070

33. Suganami T, Mieda T, Itoh M, Shimoda Y, Kamei Y, Ogawa Y. Attenuation of obesity-induced adipose tissue inflammation in $\mathrm{C} 3 \mathrm{H} / \mathrm{HeJ}$ mice carrying a Toll-like receptor 4 mutation. Biochem Biophys Res Commun. (2007) 354:45-9. doi: 10.1016/j.bbrc.2006.12.190

34. Cani PD, Amar J, Iglesias MA, Poggi M, Knauf C, Bastelica D, et al. Metabolic endotoxemia initiates obesity and insulin resistance. Diabetes (2007) 56:1761-72. doi: 10.2337/db06-1491

35. Pedro MN, Magro DO, da Silva E, Guadagnini D, Santos A, Pedro RD, et al. Plasma levels of lipopolysaccharide correlate with insulin resistance in HIV patients. Diabetol Metab Syndr. (2018) 10:7. doi: 10.1186/s13098-018-0308-7

36. Tarancon-Diez L, De Pablo-Bernal RS, Jiménez JL, Álvarez-Ríos AI, Genebat M, et al. Role of toll-like receptor 4 Asp299Gly polymorphism in the development of cardiovascular diseases in HIV-infected patients. AIDS (2018) 32:1035-41. doi: 10.1097/QAD.000000000 0001797

37. Bandera A, Masetti M, Fabbiani M, Biasin M, Muscatello A, Squillace N, et al. The NLRP3 inflammasome is upregulated in HIV-infected antiretroviral therapy-treated individuals with defective immune recovery. Front Immunol. (2018) 9:214. doi: 10.3389/fimmu.2018.00214

38. Saad MJ, Folli F, Araki E, Hashimoto N, Csermely P, Kahn CR. Regulation of insulin receptor, insulin receptor substrate-1 and phosphatidylinositol 3-kinase in 3T3-F442A adipocytes. Effects of differentiation, insulin, and dexamethasone. Mol Endocrinol. (1994) 8:545-57.

39. Zanotto TM, Quaresma PGF, Guadagnini D, Weissmann L, Santos AC, Vecina JF, et al. Blocking iNOS and endoplasmic reticulum stress synergistically improves insulin resistance in mice. Mol Metab. (2017) 6:206-218. doi: 10.1016/j.molmet.2016.12.005

40. Hirosumi J, Tuncman G, Chang L, Gorgun CZ, Uysal KT, Maeda K, et al. A central role for JNK in obesity and insulin resistance. Nature (2002) 420:333-6. doi: 10.1038/nature01137

41. Yuan M, Konstantopoulos N, Lee J, Hansen L, Li ZW, Karin M, et al. Reversal of obesity- and diet-induced insulin resistance with salicylates or targeted disruption of Ikkbeta. Science (2001) 293:1673-7. doi: 10.1126/science.1061620

42. Aguirre V, Uchida T, Yenush L, Davis R, White MF. The c-Jun NHterminal kinase promotes insulin resistance during association with insulin receptor substrate-1 and phosphorylation of Ser(307). J Biol Chem. (2000) 275:9047-54. doi: 10.1074/jbc.275.12.9047

43. Cai D, Yuan M, Frantz DF, Melendez PA, Hansen L, Lee J, et al. Local and systemic insulin resistance resulting from hepatic activation of IKK-beta and NF-kappaB. Nat Med. (2005) 11:183-90. doi: 10.1038/nm1166

44. da Silva KLC, Camacho AP, Mittestainer FC, Carvalho BM, Santos A, Guadagnini D, et al. Atorvastatin and diacerein reduce insulin resistance and increase disease tolerance in rats with sepsis. J Inflamm. (2018) 15:8. doi: 10.1186/s12950-018-0184-9
45. Castro G, CAreias MF, Weissmann L, Quaresma PG, Katashima CK, Saad $\mathrm{MJ}$, et al. Diet-induced obesity induces endoplasmic reticulum stress and insulin resistance in the amygdala of rats. FEBS Open Biol. (2013) 3:443-9. doi: 10.1016/j.fob.2013.09.002

46. Carvalho-Filho MA, Ueno M, Carvalheira JB, Velloso LA, Saad MJ. Targeted disruption of iNOS prevents LPS-induced S-nitrosation of IRbeta/IRS-1 and Akt and insulin resistance in muscle of mice. Am J Physiol Endocrinol Metab. (2006) 291:E476-82. doi: 10.1152/ajpendo.00422.2005

47. Carvalho-Filho MA, Ueno M, Hirabara SM, Seabra AB, Carvalheira JB, de Oliveira MGet al. S-nitrosation of the insulin receptor, insulin receptor substrate 1, and protein kinase B/Akt: a novel mechanism of insulin resistance. Diabetes (2005) 54:959-67. doi: 10.2337/diabetes.54.4.959

48. Ozcan L, Ergin AS, Lu A, Chung J, Sarkar S, Nie D et al. Endoplasmic reticulum stress plays a central role in development of leptin resistance. Cell Metab. (2009) 9:35-51. doi: 10.1016/j.cmet.2008.12.004

49. Willig AL, Overton ET. Metabolic complications and glucose metabolism in HIV infection: a review of the evidence. Curr HIV/AIDS Rep. (2016) 13:289-96. doi: 10.1007/s11904-016-0330-z

50. Lake JE. The fat of the matter: obesity and visceral adiposity in treated HIV infection. Curr HIV/AIDS Rep. (2017) 14:211-9. doi: 10.1007/s11904-017-0368-6

51. Lambert CT, Sandesara PB, Hirsh B, Shaw LJ, Lewis W, Quyyumi AA, et al. HIV, highly active antiretroviral therapy and the heart: a cellular to epidemiological review. HIV Med. (2016) 17:411-24. doi: 10.1111/hiv.12346

52. Miserez AR, Muller PY, Spaniol V. Indinavir inhibits sterolregulatory element-binding protein-1c-dependent lipoprotein lipase and fatty acid synthase gene activations. AIDS (2002) 16:1587-94. doi: 10.1097/00002030-200208160-00003

53. Zhou H, Gurley EC, Jarujaron S, Ding H, Fang Y, Xu Z, et al. HIV protease inhibitors activate the unfolded protein response and disrupt lipid metabolism in primary hepatocytes. Am J Physiol Gastrointest Liver Physiol. (2006) 291:G1071-80. doi: 10.1152/ajpgi.00182.2006

54. Murata H, Hruz PW, Mueckler M. Indinavir inhibits the glucose transporter isoform Glut4 at physiologic concentrations. AIDS (2002) 16:859-63. doi: 10.1097/00002030-200204120-00005

55. Murata H, Hruz PW, Mueckler M. The mechanism of insulin resistance caused by HIV protease inhibitor therapy. J Biol Chem. (2000) 275:20251-4. doi: 10.1074/jbc.C000228200

56. Carr A, Cooper DA. Adverse effects of antiretroviral therapy. Lancet (2000) 356:1423-30. doi: 10.1016/S0140-6736(00)02854-3

57. Nasi M, Pinti M, Chiesa E, Fiore S, Manzini S, Del Giovane C, et al. Decreased mitochondrial DNA content in subcutaneous fat from HIV-infected women taking antiretroviral therapy as measured at delivery. Antivir Ther. (2011) 16:365-72. doi: 10.3851/IMP1764

58. Maggiolo F, Roat E, Pinti M, Nasi M, Gibellini L, De Biasi S, et al. Mitochondrial changes during D-drug-containing once-daily therapy in HIV-positive treatment-naive patients. Antivir Ther. (2010) 15:51-9. doi: 10.3851/IMP1483

59. Galluzzi L, Pinti M, Troiano L, Prada N, Nasi M, Ferraresi R, et al. Changes in mitochondrial RNA production in cells treated with nucleoside analogues. Antivir Ther. (2005) 10:191-5.

60. Shiramizu B, Shikuma KM, Kamemoto L, Gerschenson M, Erdem G, Pinti $M$, et al. Placenta and cord blood mitochondrial DNA toxicity in HIV-infected women receiving nucleoside reverse transcriptase inhibitors during pregnancy. J Acquir Immune Defic Syndr. (2003) 32:370-4. doi: 10.1097/00126334-200304010-00004

61. Emery S, Neuhaus JA, Phillips AN, Babiker A, Cohen CJ, Gatell JM, et al. Major clinical outcomes in antiretroviral therapy (ART)-naive participants and in those not receiving ART at baseline in the SMART study. J Infect Dis. (2008) 197:1133-44. doi: 10.1086/586713

62. Funderburg NT. Markers of coagulation and inflammation often remain elevated in ART-treated HIV-infected patients. Curr Opin HIV AIDS (2014) 9:80-6. doi: 10.1097/COH.0000000000000019

63. Niv Y. Mucin genes expression in the intestine of Crohn's disease patients: A systematic review and meta-analysis. J Gastrointestin Liver Dis. (2016) 25:351-7. doi: 10.15403/jgld.2014.1121.253.niv

64. Angelovich TA, Hearps AC, Maisa A, Martin GE, Lichtfuss GF, Cheng WJ, et al. Viremic and virologically suppressed HIV infection increases 
age-related changes to monocyte activation equivalent to 12 and 4 years of aging, respectively. J Acquir Immune Defic Syndr. (2015) 69:11-7. doi: 10.1097/QAI.0000000000000559

65. Munger AM, Chow DC, Playford MP, Parikh NI, Gangcuangco LM, Nakamoto BKet al. Characterization of lipid composition and highdensity lipoprotein function in HIV-infected individuals on stable antiretroviral regimens. AIDS Res Hum Retroviruses (2015) 31:221-8. doi: 10.1089/aid.2014.0239

66. Lederman MM, Funderburg NT, Sekaly RP, Klatt NR, Hunt PW. Residual immune dysregulation syndrome in treated HIV infection. Adv Immunol. (2013) 119:51-83. doi: 10.1016/B978-0-12-407707-2.00002-3

67. van Wijk JP, Cabezas MC. Hypertriglyceridemia, metabolic syndrome, and cardiovascular disease in HIV-infected patients: effects of antiretroviral therapy and adipose tissue distribution. Int J Vasc Med. (2012) 2012:201027. doi: 10.1155/2012/201027

68. Brenchley JM, Douek DC. HIV infection and the gastrointestinal immune system. Mucosal Immunol. (2008) 1:23-30. doi: 10.1038/mi.2007.1

69. Gupta VK, Paul S, Dutta C: Geography, ethnicity or subsistence-specific variations in human microbiome composition and diversity. Front Microbiol. (2017) 8:1162. doi: 10.3389/fmicb.2017.01162

70. Rodríguez JM, Murphy K, Stanton C, Ross RP, Kober OI, Juge N, et al. The composition of the gut microbiota throughout life, with an emphasis on early life. Microb Ecol Health Dis. (2015) 26:26050. doi: 10.3402/mehd.v26.26050

71. Conlon MA, Bird AR. The impact of diet and lifestyle on gut microbiota and human health. Nutrients (2014) 7:17-44. doi: 10.3390/nu70 10017

72. Monteiro NES, Roquetto AR, de Pace F, Moura CS, Santos AD, Yamada AT, et al. Dietary whey proteins shield murine cecal microbiota from extensive disarray caused by a high-fat diet. Food Res Int. (2016) 85:121-30. doi: 10.1016/j.foodres.2016.04.036

73. Saad MJ, Santos A, Prada PO. Linking gut microbiota and inflammation to obesity and insulin resistance. Physiology (2016) 31:283-93. doi: 10.1152/physiol.00041.2015

74. Marchetti G, Bellistrì GM, Borghi E, Tincati C, Ferramosca S, La Francesca $\mathrm{M}$, et al. Microbial translocation is associated with sustained failure in $\mathrm{CD} 4+\mathrm{T}$-cell reconstitution in HIV-infected patients on long-term highly active antiretroviral therapy. AIDS (2008) 22:2035-8. doi: 10.1097/QAD.0b013e3283112d29

75. Tincati C, Douek DC, Marchetti G. Gut barrier structure, mucosal immunity and intestinal microbiota in the pathogenesis and treatment of HIV infection. AIDS Res Ther. (2016) 13:19. doi: 10.1186/s12981-016-0103-1

76. Liu J, Williams B, Frank D, Dillon SM, Wilson CC, Landay AL. Inside out: HIV, the gut microbiome, and the mucosal immune system. J Immunol. (2017) 198:605-14. doi: 10.4049/jimmunol.1601355

77. Caspari G, Beyer J, Schunter F, Knüver-Hopf J, Schmitt H. HIV-specific antibody among voluntary blood donors in Lower Saxony (FRG). Blut (1987) 55:181-7. doi: 10.1007/BF00320575

78. Vujkovic-Cvijin I, Dunham RM, Iwai S, Maher MC, Albright RG, Broadhurst MJ, et al. Dysbiosis of the gut microbiota is associated with HIV disease progression and tryptophan catabolism. Sci Transl Med. (2013) 5:193ra191. doi: 10.1126/scitranslmed.3006438

79. Srinivasa S, Fitch KV, Lo J, Kadar H, Knight R, Wong $\mathrm{K}$, et al. Plaque burden in HIV-infected patients is associated with serum intestinal microbiota-generated trimethylamine. AIDS (2015) 29:443-52. doi: 10.1097/QAD.0000000000000565

80. Wang Z, Klipfell E, Bennett BJ, Koeth R, Levison BS, Dugar B, et al. Gut flora metabolism of phosphatidylcholine promotes cardiovascular disease. Nature (2011) 472:57-63. doi: 10.1038/nature09922

81. Senthong V, Wang Z, Fan Y, Wu Y, Hazen SL, Tang WH. Trimethylamine $\mathrm{N}$-oxide and mortality risk in patients with peripheral artery disease. J Am Heart Assoc. (2016) 5:e004237. doi: 10.1161/JAHA.116.004237

82. Senthong V, Li XS, Hudec T, Coughlin J, Wu Y, Levison B, et al. Plasma Trimethylamine N-Oxide, a gut microbe-generated phosphatidylcholine metabolite, is associated with atherosclerotic burden. J Am Coll Cardiol. (2016) 67:2620-8. doi: 10.1016/j.jacc.2016.03.546

83. Zhu W, Gregory JC, Org E, Buffa JA, Gupta N, Wang Z, et al. Gut microbial metabolite TMAO enhances platelet hyperreactivity and thrombosis risk. Cell (2016) 165:111-24. doi: 10.1016/j.cell.2016.02.011
84. Organ CL, Otsuka H, Bhushan S, Wang Z, Bradley J, Trivedi R, et al. Choline diet and its gut microbe-derived metabolite, Trimethylamine $\mathrm{N}$ Oxide, exacerbate pressure overload-induced heart failure. Circ Heart Fail. (2016) 9:e002314. doi: 10.1161/CIRCHEARTFAILURE.115.002314

85. Walli R, Herfort O, Michl GM, Demant T, Jäger H, Dieterle C, et al. Treatment with protease inhibitors associated with peripheral insulin resistance and impaired oral glucose tolerance in HIV-1-infected patients. AIDS (1998) 12:F167-73. doi: 10.1097/00002030-199815000-00001

86. Hommes MJ, Romijn JA, Endert E, Eeftinck Schattenkerk JK, Sauerwein HP. Insulin sensitivity and insulin clearance in human immunodeficiency virus-infected men. Metabolism (1991) 40:651-6. doi: 10.1016/0026-0495(91)90059-6

87. Khera AV, Cuchel M, de la Llera-Moya M, Rodrigues A, Burke MF, Jafri $\mathrm{K}$, et al. Cholesterol efflux capacity, high-density lipoprotein function, and atherosclerosis. N Engl J Med. (2011) 364:127-35. doi: 10.1056/NEJMoa1001689

88. Riddler SA, Smit E, Cole SR, Li R, Chmiel JS, Dobs A, et al. Impact of HIV infection and HAART on serum lipids in men. JAMA (2003) 289:2978-82. doi: 10.1001/jama.289.22.2978

89. Jin C, Ji S, Xie T, Höxtermann S, Fuchs W, Lu X, et al. Severe dyslipidemia and immune activation in HIV patients with dysglycemia. HIV Clin Trials (2016) 17:189-96. doi: 10.1080/15284336.2016.1207297

90. (NCD-RisC) NRFC. Worldwide trends in diabetes since 1980: A pooled analysis of 751 population-based studies with 4.4 million participants. Lancet (2016) 387:1513-30. doi: 10.1016/S0140-6736(16)00618-8

91. Mujawar Z, Rose H, Morrow MP, Pushkarsky T, Dubrovsky L, Mukhamedova $\mathrm{N}$, et al. Human immunodeficiency virus impairs reverse cholesterol transport from macrophages. PLoS Biol. (2006) 4:e365. doi: 10.1371/journal.pbio.0040365

92. Ji Y, Zhang F, Zhang R, Shen Y, Liu L, Wang J, et al. Changes in intestinal microbiota in HIV-1-infected subjects following cART initiation: influence of CD4+ T cell count. Emerg Microbes Infect. (2018) 7:113. doi: $10.1038 / \mathrm{s} 41426-018-0117-y$

93. Mutlu EA, Keshavarzian A, Losurdo J, Swanson G, Siewe B, Forsyth C, et al. A compositional look at the human gastrointestinal microbiome and immune activation parameters in HIV infected subjects. PLoS Pathog. (2014) 10:e1003829. doi: 10.1371/journal.ppat.1003829

94. Nowak P, Troseid M, Avershina E, Barqasho B, Neogi U, Holm K, et al. Gut microbiota diversity predicts immune status in HIV-1 infection. AIDS (2015) 29:2409-18. doi: 10.1097/QAD.0000000000000869

95. Lozupone CA, Li M, Campbell TB, Flores SC, Linderman D, Gebert MJ, et al. Alterations in the gut microbiota associated with HIV-1 infection. Cell Host Microbe (2013) 14:329-39. doi: 10.1016/j.chom.2013.08.006

96. Li SX, Armstrong A, Neff CP, Shaffer M, Lozupone CA, Palmer BE. Complexities of gut microbiome dysbiosis in the context of HIV infection and antiretroviral therapy. Clin Pharmacol Ther. (2016) 99:600-11. doi: $10.1002 /$ cpt. 363

97. Nasi M, Pinti M, Mussini C, Cossarizza A. Persistent inflammation in HIV infection: established concepts, new perspectives. Immunol Lett. (2014) 161:184-8. doi: 10.1016/j.imlet.2014.01.008

98. Psomas C, Younas M, Reynes C, Cezar R, Portalès P, Tuaillon E, et al. One of the immune activation profiles observed in HIV-1-infected adults with suppressed viremia is linked to metabolic syndrome: the ACTIVIH study. EBioMedicine (2016) 8:265-76. doi: 10.1016/j.ebiom.2016.05.008

99. Dirajlal-Fargo S, Moser C, Brown TT, Kelesidis T, Dube MP, Stein JH, et al. Changes in insulin resistance after initiation of raltegravir or protease inhibitors with tenofovir-emtricitabine: AIDS clinical trials group A5260s. Open Forum Infect Dis. (2016) 3:ofw174. doi: 10.1093/ofid/ofw174

100. Carr A, Samaras K, Burton S, Law M, Freund J, Chisholm DJ, et al. A syndrome of peripheral lipodystrophy, hyperlipidaemia and insulin resistance in patients receiving HIV protease inhibitors. AIDS (1998) 12:F51-8. doi: 10.1097/00002030-199807000-00003

101. Carr A, Samaras K, Thorisdottir A, Kaufmann GR, Chisholm DJ, Cooper DA. Diagnosis, prediction, and natural course of HIV-1 protease-inhibitorassociated lipodystrophy, hyperlipidaemia, and diabetes mellitus: A cohort study. Lancet (1999) 353:2093-9. doi: 10.1016/S0140-6736(98)08468-2

102. Jacobson DL, Knox T, Spiegelman D, Skinner S, Gorbach S, Wanke C. Prevalence of, evolution of, and risk factors for fat 
atrophy and fat deposition in a cohort of HIV-infected men and women. Clin Infect Dis. (2005) 40:1837-45. doi: 10.1086/ 430379

103. Grinspoon S, Carr A. Cardiovascular risk and body-fat abnormalities in HIV-infected adults. N Engl J Med. (2005) 352:48-62. doi: 10.1056/NEJMra 041811

104. Hernandez D, Kalichman S, Cherry C, Kalichman M, Washington C, Grebler T. Dietary intake and overweight and obesity among persons living with HIV in Atlanta Georgia. AIDS Care (2017) 29:767-71. doi: 10.1080/09540121.2016.1238441

105. Levy ME, Greenberg AE, Hart R, Powers Happ L, Hadigan C, Castel A, et al. High burden of metabolic comorbidities in a citywide cohort of HIV outpatients: evolving health care needs of people aging with HIV in Washington, DC. HIV Med. (2017) 18:724-35. doi: 10.1111/hiv. 12516

106. Erlandson KM, Taejaroenkul S, Smeaton L, Gupta A, Singini IL, Lama JR, et al. A randomized comparison of anthropomorphic changes with preferred and alternative efavirenz-based antiretroviral regimens in diverse multinational settings. Open Forum Infect Dis. (2015) 2:ofv095. doi: 10.1093/ofid/ofv095

107. Buchacz K, Baker RK, Palella FJ, Shaw L, Patel P, Lichtenstein KA, et al. Disparities in prevalence of key chronic diseases by gender and race/ethnicity among antiretroviral-treated HIV-infected adults in the US. Antivir Ther. (2013) 18:65-75. doi: 10.3851/IMP2450

108. Achhra AC, Mocroft A, Reiss P, Sabin C, Ryom L, de Wit S, et al. Shortterm weight gain after antiretroviral therapy initiation and subsequent risk of cardiovascular disease and diabetes: the D:A:D study. HIV Med. (2016) 17:255-68. doi: 10.1111/hiv.12294

109. Bhagwat P, Ofotokun I, McComsey GA, Brown TT, Moser C, Sugar CA, et al. Changes in abdominal fat following antiretroviral therapy initiation in HIVinfected individuals correlate with waist circumference and self-reported changes. Antivir Ther. (2017) 22:577-86. doi: 10.3851/IMP3148

110. Shah RV, Murthy VL, Abbasi SA, Blankstein R, Kwong RY, Goldfine AB, et al. Visceral adiposity and the risk of metabolic syndrome across body mass index: the MESA Study. JACC Cardiovasc Imaging (2014) 7:1221-35. doi: 10.1016/j.jcmg.2014.07.017

111. McComsey GA, Moser C, Currier J, Ribaudo HJ, Paczuski P, Dubé MP, et al. Body composition changes after initiation of raltegravir or protease inhibitors: ACTG A5260s. Clin Infect Dis. (2016) 62:853-62. doi: $10.1093 / \mathrm{cid} / \mathrm{ciw} 017$

112. Centers for Disease Control and Prevention. Available online at: http://www. cdc.gov/hiv/library/reports/surveillance

113. Paisible AL, Chang CC, So-Armah KA, Butt AA, Leaf DA, Budoff M, et al. HIV infection, cardiovascular disease risk factor profile, and risk for acute myocardial infarction. J Acquir Immune Defic Syndr. (2015) 68:209-16. doi: 10.1097/QAI.0000000000000419

114. Womack JA, Chang CC, So-Armah KA, Alcorn C, Baker JV, Brown ST, et al. HIV infection and cardiovascular disease in women. J Am Heart Assoc. (2014) 3:e001035. doi: 10.1161/JAHA.114.001035

115. Friedman EE, Duffus WA. Chronic health conditions in Medicare beneficiaries 65 years old, and older with HIV infection. AIDS (2016) 30:2529-6. doi: 10.1097/QAD.0000000000001215

116. Haase J, Weyer $U$, Immig $K$, Klöting $N$, Blüher $M$, Eilers J, et al. Local proliferation of macrophages in adipose tissue during obesity-induced inflammation. Diabetologia (2014) 57:562-71. doi: 10.1007/s00125-013-3139-y

117. Bourlier V, Sengenès C, Zakaroff-Girard A, Decaunes P, Wdziekonski B, Galitzky J, et al. TGFbeta family members are key mediators in the induction of myofibroblast phenotype of human adipose tissue progenitor cells by macrophages. PLoS ONE (2012) 7:e31274. doi: 10.1371/journal.pone.0031274

118. Vandanmagsar B, Youm YH, Ravussin A, Galgani JE, Stadler K, Mynatt RL, et al. The NLRP3 inflammasome instigates obesity-induced inflammation and insulin resistance. Nat Med. (2011) 17:179-88. doi: 10.1038/nm.2279

119. Freitas P, Carvalho D, Santos AC, Matos MJ, Madureira AJ, Marques R, et al. Prevalence of obesity and its relationship to clinical lipodystrophy in HIV-infected adults on anti-retroviral therapy. J Endocrinol Invest. (2012) 35:964-70. doi: $10.3275 / 8187$
120. Rose H, Woolley I, Hoy J, Dart A, Bryant B, Mijch A, et al. HIV infection and high-density lipoprotein: the effect of the disease vs. the effect of treatment. Metabolism (2006) 55:90-5. doi: 10.1016/j.metabol.2005.07.012

121. Zangerle R, Sarcletti M, Gallati H, Reibnegger G, Wachter H, Fuchs D. Decreased plasma concentrations of HDL cholesterol in HIV-infected individuals are associated with immune activation. J Acquir Immune Defic Syndr. (1994) 7:1149-56.

122. Constans J, Pellegrin JL, Peuchant E, Dumon MF, Pellegrin I, Sergeant C, et al. Plasma lipids in HIV-infected patients: A prospective study in 95 patients. Eur J Clin Invest. (1994) 24:416-20. doi: 10.1111/j.1365-2362.1994.tb02185.x

123. Huang CY, Lu CW, Liu YL, Chiang CH, Lee LT, Huang KC: Relationship between chronic hepatitis $\mathrm{B}$ and metabolic syndrome: A structural equation modeling approach. Obesity (2016) 24:483-9. doi: 10.1002/oby.21333

124. Nagano T, Seki N, Tomita Y, Sugita T, Aida Y, Itagaki M, et al. Impact of chronic Hepatitis $C$ Virus genotype $1 \mathrm{~b}$ infection on triglyceride concentration in serum lipoprotein fractions. Int J Mol Sci. (2015) 16:20576-94. doi: 10.3390/ijms160920576

125. Fitzgerald ML, Mujawar Z, Tamehiro N. ABC transporters, atherosclerosis and inflammation. Atherosclerosis (2010) 211:361-70. doi: 10.1016/j.atherosclerosis.2010.01.011

126. McHugh J, McHugh W. How to assess deep tendon reflexes. Nursing (1990) 20:62-4. doi: 10.1097/00152193-199008000-00024

127. Rasheed S, Yan JS, Lau A, Chan AS. HIV replication enhances production of free fatty acids, low density lipoproteins and many key proteins involved in lipid metabolism: A proteomics study. PLoS ONE (2008) 3:e3003. doi: 10.1371 /journal.pone. 0003003

128. Haugaard SB, Andersen O, Pedersen SB, Dela F, Fenger M, Richelsen $\mathrm{B}$, et al. Tumor necrosis factor alpha is associated with insulinmediated suppression of free fatty acids and net lipid oxidation in HIV-infected patients with lipodystrophy. Metabolism (2006) 55:175-82. doi: 10.1016/j.metabol.2005.08.018

129. Shinohara E, Yamashita S, Kihara S, Hirano K, Ishigami M, Arai $\mathrm{T}$, et al. Interferon alpha induces disorder of lipid metabolism by lowering postheparin lipases and cholesteryl ester transfer protein activities in patients with chronic hepatitis C. Hepatology (1997) 25:1502-6. doi: 10.1002/hep.510250632

130. Zanni MV, Schouten J, Grinspoon SK, Reiss P. Risk of coronary heart disease in patients with HIV infection. Nat Rev Cardiol. (2014) 11:728-41. doi: 10.1038/nrcardio.2014.167

131. Lo J, Rosenberg ES, Fitzgerald ML, Bazner SB, Ihenachor EJ, Hawxhurst $\mathrm{V}$, et al. High-density lipoprotein-mediated cholesterol efflux capacity is improved by treatment with antiretroviral therapy in acute human immunodeficiency virus infection. Open Forum Infect Dis. (2014) 1:ofu108. doi: 10.1093/ofid/ofu108

132. El Khoury P, Ghislain M, Villard EF, Le Goff W, Lascoux-Combe C, Yeni $\mathrm{P}$, et al. Plasma cholesterol efflux capacity from human THP-1 macrophages is reduced in HIV-infected patients: impact of HAART. J Lipid Res. (2015) 56:692-702. doi: 10.1194/jlr.M054510

133. Kaplan RC, Hanna DB, Kizer JR. Recent insights into cardiovascular disease (CVD) risk among HIV-infected adults. Curr HIV/AIDS Rep. (2016) 13:44-52. doi: 10.1007/s11904-016-0301-4

134. Triant VA, Lee H, Hadigan C, Grinspoon SK. Increased acute myocardial infarction rates and cardiovascular risk factors among patients with human immunodeficiency virus disease. J Clin Endocrinol Metab. (2007) 92:2506-12. doi: 10.1210/jc.2006-2190

135. Rockstroh JK. Non-Alcoholic Fatty Liver Disease (NAFLD) and NonAlcoholic Steatohepatitis (NASH) in HIV. Curr HIV/AIDS Rep. (2017) 14:47-53. doi: 10.1007/s11904-017-0351-2

136. Guaraldi G, Lonardo A, Maia L, Palella FJ. Metabolic concerns in aging HIVinfected persons: from serum lipid phenotype to fatty liver. AIDS (2017) 31 (Suppl. 2):S147-56. doi: 10.1097/QAD.0000000000001483

137. Morse CG, McLaughlin M, Matthews L, Proschan M, Thomas F, Gharib $\mathrm{AM}$, et al. Nonalcoholic steatohepatitis and hepatic fibrosis in HIV-1monoinfected adults with elevated aminotransferase levels on antiretroviral therapy. Clin Infect Dis. (2015) 60:1569-78. doi: 10.1093/cid/civ101

138. Macias J, Rivero-Juarez A, Neukam K, Tellez F, Merino D, Frias M, et al. Impact of genetic polymorphisms associated with nonalcoholic 
fatty liver disease on HIV-infected individuals. AIDS (2015) 29:1927-35. doi: 10.1097/QAD.0000000000000799

139. Price JC, Seaberg EC, Latanich R, Budoff MJ, Kingsley LA, Palella FJ, et al. Risk factors for fatty liver in the multicenter AIDS cohort study. Am J Gastroenterol. (2014) 109:695-704. doi: 10.1038/ajg.2014.32

140. Crum-Cianflone N, Dilay A, Collins G, Asher D, Campin R, Medina S, et al. Nonalcoholic fatty liver disease among HIV-infected persons. J Acquir Immune Defic Syndr. (2009) 50:464-73. doi: 10.1097/QAI.0b013e318198a88a

141. Sterling RK, Smith PG, Brunt EM. Hepatic steatosis in human immunodeficiency virus: A prospective study in patients without viral hepatitis, diabetes, or alcohol abuse. J Clin Gastroenterol. (2013) 47:182-7. doi: 10.1097/MCG.0b013e318264181d

142. Younossi Z, Anstee QM, Marietti M, Hardy T, Henry L, Eslam M, et al. Global burden of NAFLD and NASH: trends, predictions, risk factors and prevention. Nat Rev Gastroenterol Hepatol. (2018) 15:11-20. doi: 10.1038/nrgastro.2017.109

143. Antinori A, Arendt G, Becker JT, Brew BJ, Byrd DA, Cherner M, et al. Updated research nosology for HIV-associated neurocognitive disorders. Neurology (2007) 69:1789-99. doi: 10.1212/01.WNL.0000287431.88658.8b

144. Ghafouri M, Amini S, Khalili K, Sawaya BE. HIV-1 associated dementia: symptoms and causes. Retrovirology (2006) 3:28. doi: 10.1186/1742-4690-3-28

145. Sacktor N, McDermott MP, Marder K, Schifitto G, Selnes OA, McArthur JC, et al. HIV-associated cognitive impairment before and after the advent of combination therapy. J Neurovirol. (2002) 8:136-42. doi: 10.1080/13550280290049615

146. Chan P, Brew BJ. HIV associated neurocognitive disorders in the modern antiviral treatment era: prevalence, characteristics, biomarkers, and effects of treatment. Curr HIV/AIDS Rep. (2014) 11:317-24. doi: 10.1007/s11904-014-0221-0
147. Triant VA, Brown TT, Lee H, Grinspoon SK. Fracture prevalence among human immunodeficiency virus (HIV)-infected versus non-HIV-infected patients in a large U.S. healthcare system. J Clin Endocrinol Metab. (2008) 93:3499-504. doi: 10.1210/jc.2008-0828

148. Collin F, Duval X, Le Moing V, Piroth L, Al Kaied F, Massip Pet al. Ten-year incidence and risk factors of bone fractures in a cohort of treated HIV1-infected adults. AIDS (2009) 23:1021-4. doi: 10.1097/QAD.0b013e3283292195

149. Shiels MS, Cole SR, Kirk GD, Poole C. A meta-analysis of the incidence of non-AIDS cancers in HIV-infected individuals. J Acquir Immune Defic Syndr. (2009) 52:611-22. doi: 10.1097/QAI.0b013e3181b327ca

150. Yanik EL, Katki HA, Engels EA. Cancer risk among the HIVinfected elderly in the United States. AIDS (2016) 30:1663-8. doi: 10.1097/QAD.0000000000001077

151. Currier JS, Taylor A, Boyd F, Dezii CM, Kawabata H, Burtcel B, et al. Coronary heart disease in HIV-infected individuals. I Acquir Immune Defic Syndr. (2003) 33:506-12. doi: 10.1097/00126334-2003080 10-00012

Conflict of Interest Statement: The authors declare that the research was conducted in the absence of any commercial or financial relationships that could be construed as a potential conflict of interest.

Copyright (c) 2018 Pedro, Rocha, Guadagnini, Santos, Magro, Assalin, Oliveira, Pedro and Saad. This is an open-access article distributed under the terms of the Creative Commons Attribution License (CC BY). The use, distribution or reproduction in other forums is permitted, provided the original author(s) and the copyright owner(s) are credited and that the original publication in this journal is cited, in accordance with accepted academic practice. No use, distribution or reproduction is permitted which does not comply with these terms. 